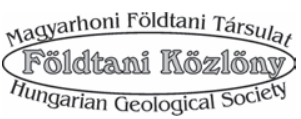

151/1, 65-78., Budapest, 2021

DOI: 10.23928/foldt.kozl.2021.151.1.65

\title{
Review of geothermal conditions of Hungary
}

\author{
LenKey, László*, MihályKa, János, PARócZi, Petra \\ Department of Geophysics and Space Science, Eötvös Loránd University, \\ *correspondent author: lenkey@ caesar.elte.hu \\ mihalyka.janos@ttk.elte.hu \\ petraparoczi@gmail.com
}

\section{Magyarország geotermikus viszonyainak áttekintése}

Összefoglalás

Jelen cikkben a hőáramot és a felszín alatti hőmérsékletet mutatjuk be Magyarország területén. Magyarország hőáramtérképét 2002-ben publikálták Európa Gotermikus Atlaszában, és Magyarország Geotermikus Adatbázisát $2005-$ ben frissítették utoljára. Azóta több geotermikus projekt is befejeződött, melyek keretében új hőmérsékletet mértek, vagy a kutatási területen korábban végzett mérések adatait szedték össze (TransEnergy [2010-13], Dráva Geotermikus projekt [2014], Paks-II [2016]), valamint az azóta mélyített kutatófúrásokban is mértek hőmérsékletet. Időszerúvé vált az adatbázis frissítése, és az adatok bemutatása hőáramtérkép, valamint hômérséklettérképek formájában.

A hőáramot Fourier elsô törvénye alapján számítjuk, miszerint a hőáram a kőzetek hővezetőképességének és a hőmérséklet-gradiensnek a szorzata. A kőzetek hővezetőképességét laboratóriumban fúrási magmintákon mérik. A fúrásokban mért hőmérsékleteket, a fúrások rétegsorát és az abból becsült hővezetőképességet Magyarország Geotermikus Adatbázisában tároljuk. Ezen adatok segítségével számoltuk a hőáramot és a hőmérséklet-mélység függvényt a fúrásokban, melyeket térképekkel szemléltettünk.

2001 darab 1 km-nél mélyebb fúrásban határoztuk meg a hőáramot a Bullard-plot módszer segítségével. A hőáram Magyarországon $30 \mathrm{~mW} / \mathrm{m}^{2}$ és $120 \mathrm{~mW} / \mathrm{m}^{2}$ között változik, az átlagos hőáram $90 \mathrm{~mW} / \mathrm{m}^{2}$. A magas hóáram a középsó miocén során végbement litoszféra-megnyúlás következménye. A maximális értékek az ország D-i részén találhatók, míg a minimális értékek a karsztvíz-beszivárgási területeken fordulnak elô. Az üledékes részmedencékben (pl. Makói-árok), ahol a neogén és negyedidőszaki üledékek vastagsága meghaladja az 5-7 km-t, a hőáram a medencére jellemzó átlag alatt van $\left(80 \mathrm{~mW} / \mathrm{m}^{2}\right)$, főleg mert az üledékek még nem tudtak teljesen átmelegedni, kisebb részben pedig azért, mert az üledékek alacsony hővezetőképessége miatt a hőáram az aljzatmagaslatok felé eltérül.

A geotermikus energiahasznosítás szempontjából az egyik legfontosabb tényező a felszín alatti hőmérséklet. 500 mben, 1 km-ben, 2 km-ben és 3 km-ben kiszámoltuk a hőmérsékletet és térképeken ábrázoltuk. Az átlaghőmérséklet ezekben a mélységhorizontokban rendre $40^{\circ} \mathrm{C}, 60^{\circ} \mathrm{C}, 100^{\circ} \mathrm{C}$ and $140^{\circ} \mathrm{C}$. A geotermikus gradiens mélységgel történô csökkenését a kőzetek hővezetőképességének növekedése okozza. A hőáramhoz hasonlóan a hőmérsékletet is nagyban befolyásolják a felszín alatti vízáramlások. A negyedidőszaki és neogén üledékekben zajló vízáramlás leginkább a felső 1 kmes mélységtartományban okoz hőmérsékletanomáliákat, melyek a mélységgel lecsengenek (pl. Tiszakécske). Ennek az az oka, hogy porózus-permeábilis üledékek $2 \mathrm{~km}$ mélységig fordulnak elő. A karsztosodott karbonátos medencealjzatban zajló áramlás az aljzatig befolyásolja a hőmérsékletet, vagyis akár 3-4 km-es mélységig.

Tárgyszavak: höáram, geotermikus gradiens, hövezetốképesség, felszín alatti vízáramlás

Abstract

The heat flow map of Hungary was presented in the Atlas of Geothermal Resources in Europe in 2002 and was last updated in 2005. Since that time several geothermal projects, e.g. TransEnergy (2010-13), assessment of the geothermal potential of the Dráva Basin (2013), Paks-II NPP (2016) and continuous drilling activity in the country have been in progress. Large amount of temperature data became available, which allowed the update of the Geothermal Database of Hungary and the compilation of an updated heat flow map and temperature maps.

The heat flow is determined based on the Fourier law using the thermal conductivities of rocks and temperature gradient calculated from temperature observations in boreholes and wells. The thermal conductivity is known from laboratory measurements made on core samples. The thermal conductivities and the temperature data are stored in the Geothermal Database of Hungary. 
The heat flow is calculated in 2001 boreholes and wells deeper than $1 \mathrm{~km}$ using the Bullard-plot technique. The mean heat flow in Hungary is $90 \mathrm{~mW} / \mathrm{m}^{2}$, varying between $30 \mathrm{~mW} / \mathrm{m}^{2}$ and $120 \mathrm{~mW} / \mathrm{m}^{2}$. The high heat flow is due to the Middle Miocene extension of the lithosphere. The high values are found over buried basement highs in the eastern and southern part of the country, while the low values are located in the recharge areas of karstic flow systems. In the sedimentary basins, where the thickness of the Neogene and Quaternary sediments reaches 5-7 km, the heat flow is slightly below the mean value $\left(80-90 \mathrm{~mW} / \mathrm{m}^{2}\right)$. It is mainly due to the cooling effect of sedimentation and lesser degree to the heat refraction caused by the low thermal conductivity of sediments.

Temperature maps at $500 \mathrm{~m}, 1 \mathrm{~km}, 2 \mathrm{~km}$ and $3 \mathrm{~km}$ depths were also compiled. The mean temperature in these depths is $40{ }^{\circ} \mathrm{C}, 60{ }^{\circ} \mathrm{C}, 100^{\circ} \mathrm{C}$ and $140{ }^{\circ} \mathrm{C}$, respectively. The decrease of geothermal gradient is due to the increase of thermal conductivity with depth. Similarly to the heat flow, the temperature anomalies strongly reflect the local and regional groundwater flow systems. Groundwater flow in the sedimentary basins mainly influences the heat flow in the upper $1 \mathrm{~km}$, because porous-permeable sediments occur until $2 \mathrm{~km}$ depth. Groundwater flow in the karstic basement influences the temperature until the basement depth, that is until 3-4 km depth.

Key words: heat flow, geothermal gradient, thermal conductivity, groundwater flow

\section{Introduction}

On global scale the temperature difference between the cold surface of the Earth and the hot interior part drives mantle convection and plate tectonics. On regional scale the subsurface temperature structure of the lithosphere determines the mineralogical and rheological states of the mantle and crust (RANALLI 1995). The temperature variations together with the mineral composition control the strength of the lithosphere influencing its tectonic history, and vice versa, tectonic processes leave a signature in the temperature field (Cloetingh et al. 2010). On local scale the temperature distribution in the crust is one of the key factors in geothermal energy utilization. In the Pannonian Basin the tectonic evolution of the basin resulted in high geothermal gradient, coupled with deposition of porous sediments, which partly cover fractured and karstified Mesozoic carbonates (MAGYAR et al. 2013, HoRvÁTH et al. 2015). The two processes led to the formation of geothermal reservoirs in the Mesozoic carbonates (ALFÖLDI 1979, MÁDL-SzŐNYI \& TótH 2015) and the Neogene sediments (KORIM 1972, BÁLINT \& SZANYI 2015), which have been used for bathing for hundreds of years, and for heating purposes for the last seventy years (NÁDOR et al. 2019a).

In this paper we present the temperature field in the upper $3 \mathrm{kms}$ of the crust and the heat flow in Hungary based on the most recent data.

\section{History of geothermal data in Hungary}

SZANYI et al. (2021) in this volume presented the detailed history of the geothermal research, exploration and utilization in Hungary. In this paper we mention only those milestones, which significantly contributed to our knowledge of the geothermal conditions of Hungary. Geothermal data are mainly connected to geothermal and hydrocarbon exploration and production, and to lesser extent to other drilling activities. Geothermal exploration in Hungary started by the drilling of the $970 \mathrm{~m}$ deep well in the City Park in Budapest by Vilmos ZsigmONDY in 1878 (ZsigmONDY 1879). Now the well is in standby and in case of need it could supply thermal water with temperature of $74{ }^{\circ} \mathrm{C}$ from Triassic dolomites. In the 1920's extensive hydrocarbon exploration went on in the Great Hungarian Plain, but the drillings, appointed by Ferenc PÁVAI VAJNA, found gaseous thermal water coming from Neogene sediments e.g. at Hajdúszoboszló, Karcag, Debrecen, Szeged, etc. The water at Hajdúszoboszló comes from $1020 \mathrm{~m}$ depth and it has a temperature of $70{ }^{\circ} \mathrm{C}$. The geothermal gradient calculated from the temperatures of the wells at the City Park and Hajdúszoboszló is in the range of $57-64{ }^{\circ} \mathrm{C} / \mathrm{km}$, which is higher than the mean value of the continental crust $\left(33^{\circ} \mathrm{C} / \mathrm{km}\right.$, PoLlACK et al. 1993). At the time of discovering the geothermal reservoirs in Hungary it was not clear why the gradient was so high. Tibor BoLDIZSÁR, a young mining engineer made the first heat flow determination in Hungary in a coal mine shaft at Komló (BoLDIzSÁr 1956). It was the third heat flow determination in Europe after the first one in Wales (Lord KELVIN 1863) and the second one in the Gothard Railway Tunnel in Switzerland (STAPFF 1883). BOLDIZSÁR measured the temperature gradient and the thermal conductivity of the rocks, and he arrived to heat flow density of $138 \mathrm{~mW} / \mathrm{m}^{2}$. Later he constructed the first heat flow map of Hungary (BoLDIZSÁR 1967), and it became clear that the heat flow in Hungary was over the continental average $\left(65 \mathrm{~mW} / \mathrm{m}^{2}\right.$, POLLACK et al. 1993). With the increasing number of thermal wells the Water Management Research Institute (VITUKI) edited the first cadaster of the thermal wells (BÉLTEKY et al. 1965), which was regularly updated later. It was the first geothermal database of Hungary, which contained the depth of screening, bottom hole temperature, temperature at well head, water yield and chemistry of water. Since 2014, after the cease of VITUKI, the registration of new thermal wells and the update of the cadaster have been carried out by the Hungarian Mining and Geological Survey. Recently a new thermal cadaster was compiled by TóTH (2016) for the public to accelerate the utilization of geothermal energy in Hungary. It lists the thermal wells, the temperature at well head and the water yield. The Hungarian Oil Company also measures routinely the temperature in hydrocarbon exploration boreholes and records the circumstances of the measurements, 
and the former Hungarian Geological Institute (MÁFI) also carried out temperature measurements in exploration wells. In 1983 Péter DöVÉNYI merged the oil industry data, the MÁFI data and the data of the VITUKI thermal cadasters, and he created the most comprehensive geothermal database of Hungary at that time (DövÉNYI et al. 1983). The database also included thermal conductivity of rocks measured in the laboratory of the Department of Geophysics of the Eötvös Loránd University (ERKI 1984). 19 out of 28 heat flow determinations in Hungary were carried, by Péter DöVÉNYI and Ferenc HORVÁTH during the 1980's (for summary see DövÉNYI et al. 2002). The utilization of geothermal reservoirs deeper than $2500 \mathrm{~m}$ is regulated by concessional law in Hungary. 17 geothermal concessional areas have been defined, and reports about their geothermal conditions, including up-to-date temperature data from boreholes and wells, were compiled at the Hungarian Mining and Geological Survey (ZILAHI-SEBESS \& GYURICZA 2011-13).

The recently used Geothermal Database of Hungary has been developed by Péter DövÉNYI (DövÉNYI 1994). It contains temperature data measured deeper than $200 \mathrm{~m}$, or data with temperature higher than $30^{\circ} \mathrm{C}$. The data are quality controlled depending on the type and circumstances of the measurement. The database also contains the lithology of the borehole, which enables thermal conductivity estimates. It was last updated in 2005 (REZESSY et al. 2005). Since that time several geothermal projects have been carried out though: e.g. TransEnergy (RoTÁR-SZALKAI et al. 2017), Drava-basin geothermal project (HORVÁTH et al. 2014, NÁDOR et al. 2019b), Paks-2 Nuclear Power Plant (2016), where either new temperature measurements were made or existing data from the project area were collected. Additionally, some dozens of deep hydrocarbon exploration boreholes were drilled, and a few of them are deeper than $6000 \mathrm{~m}$. Large amount of temperature data became available, which allowed the update of the Geothermal Database of Hungary. The database presently contains 14462 temperature data measured in 5023 boreholes and wells.

\section{Temperature data}

Most temperature measurements are carried out in a borehole or well usually after stopping the drilling or the production. These temperatures are disturbed by the mud circulation or the fluid flow in the well, and they do not represent the true temperature of the rock. After stopping the operations in the borehole the temperature begins to recover to its undisturbed state. In case of repeated measurements, the bottom hole temperatures (BHT) can be corrected following the methods of HORNER (1951), DOwDLE \& COBB (1975). If only one reading happened its value is corrected with the mean value of the corrections in the database. Temperature measurements during capacity tests, drill stem test temperatures (DST) or temperature of fluid, mainly water, flowing into the well may represent the true rock temperature, if the depth of measurement is in the screened section of the well or slightly below the screening, and the production layer is a few tens of meters, the layer is horizontal and secondary effects e.g. expansion of gas are negligible. Such conditions often exist in wells in Hungary or it is possible to check if they prevail. There are many water temperature data measured at the wellhead. Such data were corrected using the empirical formula of GÁLFI \& LIEBE (1977) in order to obtain the temperature at the screening. The corrected temperature is referred to the middle of the screened section, which is often tens of meters, or sometimes hundreds of meters reducing the quality of the data. The most reliable temperatures are the steady state ones. Those wells are regarded to be in steady state, where two years have passed since the termination of the last operation in the well. Unfortunately, the number of steady state wells and temperature data are very limited.

The Geothermal Database of Hungary contains the names of the wells and boreholes, coordinates, elevation above the sea level, depth of the temperature measurement, method of the measurement as types listed above, the observed value and the simplified lithology of the well. The correction of the observed values is made automatically using the methods mentioned above. The reliability of the temperature data varies according to the type of the data and the circumstances of the observation. The temperature data are ranked into 9 classes according to their reliability: first class is the best, ninth is the worst. Steady state temperatures are ranked to the first class, they are followed by the DST data, capacity measurements and inflowing fluid temperatures. Usually BHT values are ranked into higher class depending on the correction and the worst classes are the temperatures observed on the well head. As it is shown in Figure 1 even corrected temperature data have large scatter and their weighted mean represents best the "true rock" temperature. In general, the standard deviation of temperature data is $10 \%$.

Figure 2 shows the locations of the boreholes and wells, where temperature observations were made. The aerial coverage of the country is quite good, except the Cserhát, Bükk and Tokaj Mountains, and the regions NW and SE of Paks, SE of Budapest and Bereg region. The best surveyed areas are the hydrocarbon fields. In 33\% of the wells only one, in $13 \%$ of the wells more than five temperature data exist.

\section{Thermal conductivity of rocks}

The thermal state of the lithosphere can be inferred from the heat flow density (shortly heat flow). It is calculated using the Fourier Law:

$$
q=-\lambda \nabla T
$$

where $\boldsymbol{q}$ is the heat flow, $\lambda$ is the thermal conductivity of the rock and $\nabla T$ is the temperature gradient. In practice we determine the vertical component of the heat flow, which is the dominant one, using the simplified version of the Fourier Law:

$$
q_{z}=-\lambda \frac{\Delta \mathrm{T}}{\Delta \mathrm{z}}
$$




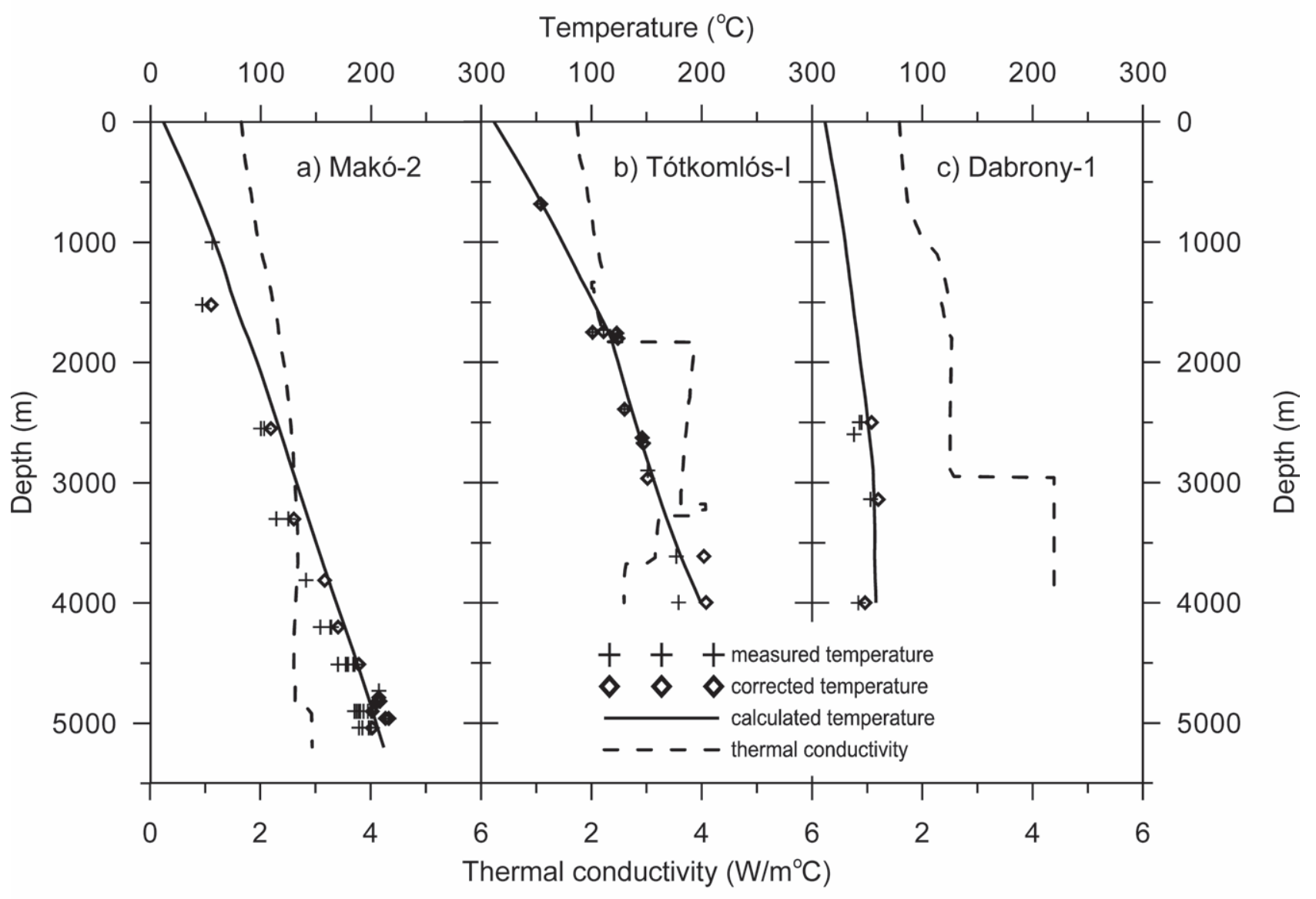

Figure 1. Measured, corrected and extrapolated (calculated) temperatures, and estimated thermal conductivities in the (a) Makó-2, (b) Tótkomlós-I, (c) Dabrony-1 boreholes. Lithology of Makó-2 borehole: Neogene sediments $4860 \mathrm{~m}$, Lower Triassic dolomite $5080 \mathrm{~m}$. Lithology of Tótkomlós-I borehole: Quaternary sediments 390 m, Neogene sediments 1795 m, Middle Triassic dolomite 3165 m, Lower Triassic sandstone 3260 , Permian quartz porfir 3637 m, Precambrian granite, migmatite 3992 m. Lithology of Dabrony-1 borehole: Neogene sediments 1764 m, Upper Cretaceous sediments (Senonian) 2897 m, Upper Triassic dolomite $4001 \mathrm{~m}$

1. ábra. Mért, korrigált és számított hömérséklet, valamint a becsült hövezetöképesség a (a) Makó-2, (b) Tótkomlós-I és (c) Dabrony-1 fúrásokban. A Makó-2 fúrás rétegsora: neogén üledékek $4860 \mathrm{~m}$, alsó triász dolomit $5080 \mathrm{~m}$. A Tótkomlós-I fúrás rétegsora: negyedidőszaki üledékek $390 \mathrm{~m}$, neogén üledékek 1795 m, középsö triász dolomit 3165 m, alsó triász homokkö 3260 m, permi kvarcporfir 3637 m, prekambriumi gránit és migmatit 3992 m. A Dabrony-1 fúrás rétegsora: neogén üledékek 1764 m, felsö kréta üledékek (szenon) 2897 m, felső triász dolomit 4001 m. Kereszt: mért hömérséklet, rombusz: korrigált hömérséklet, folytonos vonal: számított hömérséklet, szaggatott vonal: hövezetöképesség

where the vertical gradient (the geothermal gradient) is approximated with the vertical temperature difference ratio $(\Delta T / \Delta z)$.

In order to determine the heat flow, thermal conductivity of core samples from 20 wells were measured in laboratory. The samples were coated by paraffin or packed in nylon bag to prevent them from drying out or were refilled by water in vacuum in the laboratory. More than 300 sediment samples and 50 samples of other rock types were measured (ERKI 1984) and conductivity-depth functions were established for shales and sandstones (Figure 3, after DövÉNYI \& HoRVÁTH 1988). The Geothermal Database of Hungary contains the lithological description of the boreholes and wells. Based on the shale to sand ratio deduced from the lithological description the thermal conductivity of sediments in a given borehole is estimated using the conductivity-depth trends of Figure 3. In cases where the ratio is not known the shale to sand ratio is assumed to be 0.5 . The thermal conductivity of other rocks in the database is taken from the literature (KAPPELMEYER \& HAENEL 1974).

In general, the thermal conductivity of clastic sediments is lower than the conductivity of the basement composed of carbonates or crystalline rocks. When heat is transported by conduction the heat flow is constant on the depth scale of the boreholes. Assuming conduction and constant heat flow it follows from Eqs. 1 and 2 that the geothermal gradient in the clastic sediments is higher than in the basement as evidenced in the Tótkomlós-I well (Figure $1 b$ ). The sediments, which have low thermal conductivity, act as a heat insulating layer; mechanism called thermal blanketing. In deep basins the effect is smaller, because the thermal conductivity of sediments increases with depth due to compaction and diagenesis (Figures 1 and 3), and the contrast with the thermal conductivity of crystalline rocks decreases. The increase of thermal conductivity with depth is the main reason of the decrease of the geothermal gradient with depth in Hungary. 


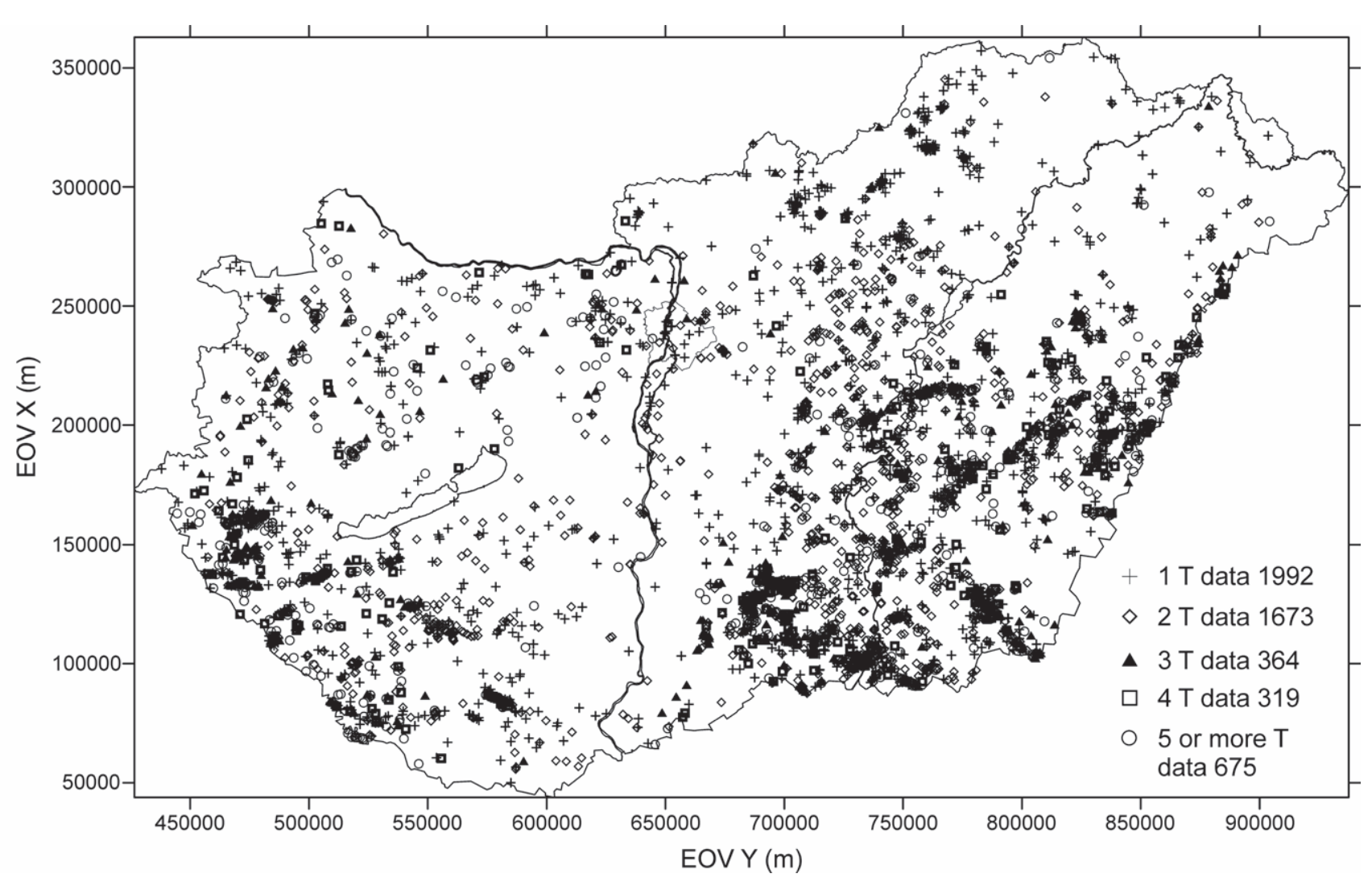

Figure 2. Location of boreholes and wells, where temperature observations were made. In the lower right corner the number of temperature data in the boreholes and wells is given

2. ábra. Fúrások és kutak, melyekben hömérsékletmérést végeztek. A jobb alsó sarokban azon fúrások, illetve kutak száma látszik, melyekben 1, 2, 3, 4, 5 vagy több hömérsékletet mértek

A thermal conductivity-depth relationship for the Tertiary sediments in Hungary is based on an average porositydepth relationship determined from well logs (ZILAHI-SEBESS et al. 2008). It looks like the mean of the two trends presented in Figure 3, and it is mainly used in assessing the geothermal gradient in the concessional areas (ZILAHI-SEBESS \& GYURICZA 2011-13). A present research is going on to determine the thermal conductivity of sediments using well logs. The volume of sand, clay and water is calculated from the logs then the thermal conductivity is calculated as

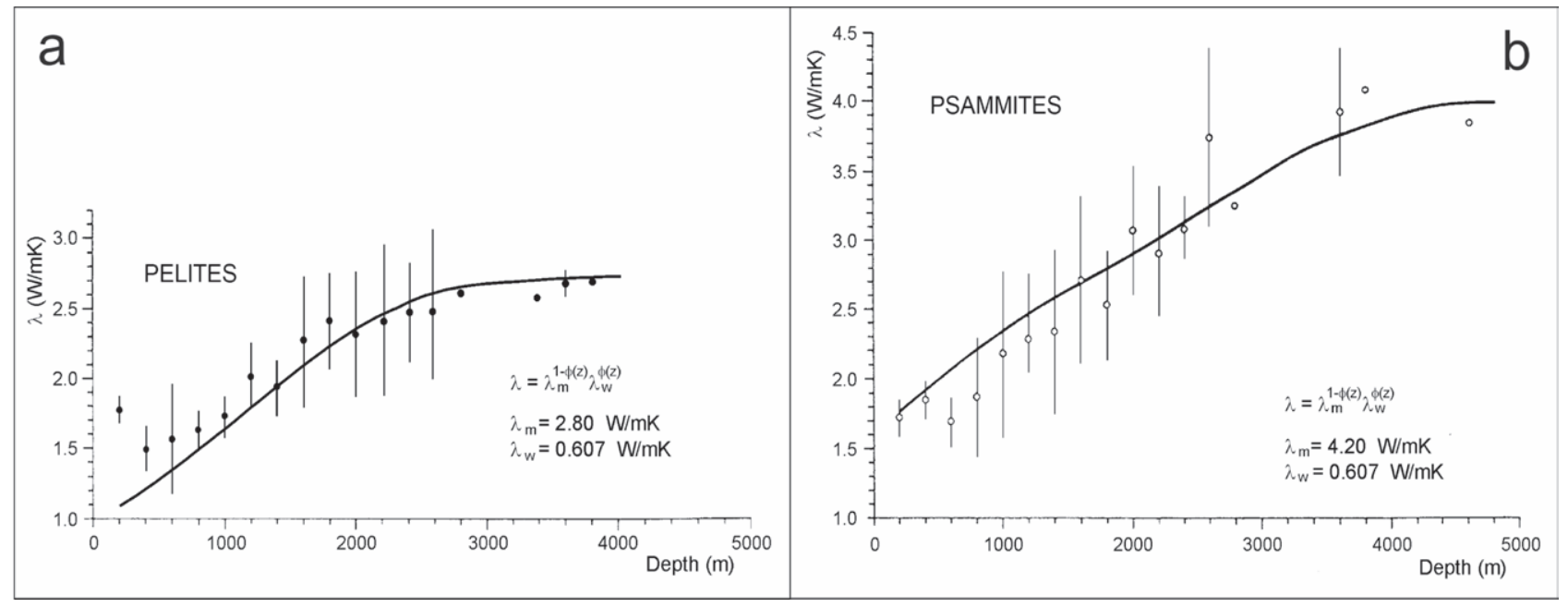

Figure 3. Thermal conductivity-depth functions of Neogene and Quaternary pelites (a) and psammites (b) based on laboratory measurements (DövÉNYI \& HORVÁTH 1988)

3. ábra. A neogén és negyedidöszaki (a) pélitek és (b) pszammitok hövezetöképessége ᄀa mélység függvényében laboratóriumi mérések alapján (DöVÉNYI \& HoRVÁTH 1988) 
the weighted harmonic mean of the components. The method is calibrated with the available thermal conductivities measured in laboratory (ERKI 1984). It allows a more accurate and consistent determination of the thermal conductivity of sediments compared to the presently used methods. At this moment we processed well logs from seven boreholes. As $70 \%$ of the country is covered by sediments, and most of the temperature observations were made in sediments the new method can be applied in most of the boreholes and wells in the future.

\section{Heat flow and subsurface temperature in Hungary and their interpretation}

Heat flow was calculated applying the Bullard-plot technique (BULLARD 1939). During the calculation the reliability of the temperature data was taken into account by giving higher weight to the more reliable data, and the mean heat flow characteristic for the borehole was calculated (see Appendix). According to formula A1 (Appendix), we could calculate the heat flow $\left(q_{i}\right)$ as the function of depth in those boreholes where temperatures were observed in several depths. From this viewpoint those boreholes are relevant, where four or more temperature data are available (see Figure 1). Outside the recharge and discharge areas of karstic reservoirs and with the exception of a few boreholes (e.g. Szombathely-II, or wells at Tiszakécske) the heat flow does not vary significantly with depth. This is mainly true in the sedimentary areas. However, care should be taken in the covered karstic areas, because in the sedimentary cover conduction dominates, but in the reservoir convection might occur. Thus, heat flow is constant in the cover, but it might change in the reservoir. In Figure 4 the temperature and heat flow is shown in a reservoir, where upward or downward groundwater flow is taking place (after BREDEHOEFT \& PAPADOPUlOS 1965). Upward groundwater flow transports heat upward resulting in high near surface temperature, and thus high geothermal gradient and heat flow, but both quantities decay with depth. In case of downward groundwater flow the opposite happens. The same processes should occur in the covered reservoirs too, but unfortunately, the heat flow variation very often is not detected by temperature observations, because most of the boreholes penetrated the karstic (Triassic) basement only a few meters, and then the drilling stopped. For example, Dabrony-1 well is located in the Little Hungarian Plain, at the northwestern feet of the Transdanubian Range, where Triassic carbonates are found in $3 \mathrm{~km}$ depth beneath the Neogene and Cretaceous sediments. Karstic water of meteoric origin, recharged at the outcrop of the Triassic carbonates in the Transdanubian Range, seeps towards the northwest and cools the basement and the overlying sedimentary sequence. The resulting gradient $\left(15.3{ }^{\circ} \mathrm{C} / \mathrm{km}\right)$ and heat flow $\left(32 \mathrm{~mW} / \mathrm{m}^{2}\right)$ are very low (Figure 1c). The opposite happens at the Városliget-I well, where the karstic water flows upwards and towards the warm springs at the Danube River. Both the geothermal gradient $\left(64{ }^{\circ} \mathrm{C} / \mathrm{km}\right)$ and the heat flow $\left(143 \mathrm{~mW} / \mathrm{m}^{2}\right)$ calculated in the well are higher than the average values in Hungary.

It is evident that very low or very high geothermal gradient and heat flow indicate groundwater flow, and in spite of the fact that the observed heat flow seems to be constant in the borehole it must vary with depth. In such cases the temperature field and heat flow can be calculated by numerical modelling, which takes into account the groundwater flow and based on geological, hydrogeological and geophysical observations and data.

The heat flow map shown in $\mathrm{Fi}$ gure 5 is based on data from 2001 boreholes and wells deeper than 1 $\mathrm{km}$. The heat flow was calculated using formulas A1 and A2 (Appendix). Paleoclimatic correction was not applied. The accuracy of the heat flow determination in the bore-
Figure 4. Temperature and heat flow profiles in a groundwater reservoir, where vertical water flow takes place (BREDEHOEFT \& PAPAdopulos 1965). The Peclet-number is 4 (Peclet-number gives the ratio of the convective and conductive heat flows). Thermal conductivity is $2 \mathrm{~W} / \mathrm{m}^{\circ} \mathrm{C}$, thus the conductive heat flow is $90 \mathrm{~mW} / \mathrm{m}^{2}$

4. ábra. Hömérséklet és höáramsürüség a mélység függvényében egy felszín alatti vízrezervoárban, ahol függöleges irányú vizáramlás zajlik (BREDEHOEFT \& PAPADOPULOS 1965). A Peclet-szám 4. (A Peclet-szám a konvektív és konduktív höáramsürüség aránya.) A hövezetóképesség $2 \mathrm{~W} / \mathrm{m}^{\circ} \mathrm{C}$. Ezzel az értékkel számolva a konduktív höáramsürüség $90 \mathrm{~mW} / \mathrm{m} 2$. Folytonos vonal: feláramlás, szaggatott vonal: leáramlás 


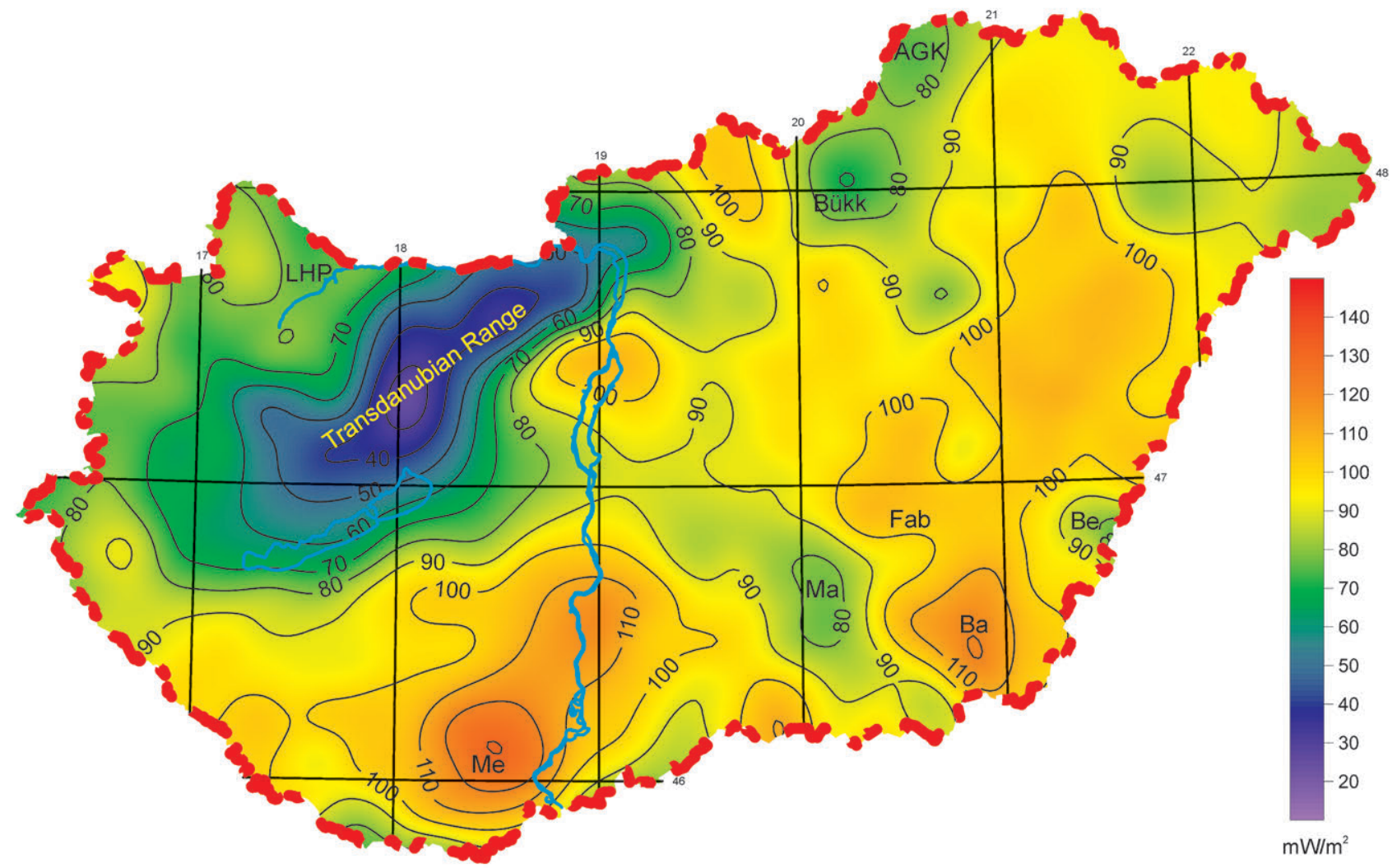

Figure 5. Heat flow in Hungary. The contour interval is $10 \mathrm{~mW} / \mathrm{m}^{2}$

LHP: Little Hungarian Plain, Me: Mecsek Mts., Ma: Makó Trough, Be: Békés depression, Ba: Battonya basement high, AGK: Aggtelek-Gömör Karst

5. ábra: Höáramsürüség Magyarországon. Az izovonalak osztásköze $10 \mathrm{~mW} / \mathrm{m}^{2}$

LHP: Kisalföld, Me: Mecsek, Ma:Makói-árok, Be: Békési-süllyedék, Ba: Battonya-Pusztafölvári-hátság, AGK:Aggtelek-Gömöri-karszt

holes and wells is estimated to be $\pm 15 \%$ due to errors in temperature observations and thermal conductivity assessment. The isoline contouring of Figure 5 was made by kriging.

The heat flow in Hungary varies between $30 \mathrm{~mW} / \mathrm{m}^{2}$ and $120 \mathrm{~mW} / \mathrm{m}^{2}$ with lowest values in the Transdanubian Range and highest values in the southern part of the country. The average value is $90 \mathrm{~mW} / \mathrm{m}^{2}$, which is higher than the mean continental heat flow of $65 \mathrm{~mW} / \mathrm{m}^{2}$ (PoLlaCK et al. 1993, JAUPART et al. 2007). The high heat flow is due to Middle Miocene (17.5-12.5 Ma) lithospheric extension in the Pannonian Basin (RoYDEN et al. 1983, LENKEY 1999, HoRVÁTH et al. 2015) resulting in thin lithosphere and elevated asthenosphere. If extension occurs by pure shear in less than 15 million years the temperature gradient, and consequently the heat flow, increases in the lithosphere (Figure 6) (McKenZIE 1978, JARvis \& McKenZIE 1980). Already the first study has showed that the high post-rift subsidence rate and high present-day heat flow can be explained only if the mantle part of the lithosphere thinned considerably more

$\rightarrow$ Figure 6. Pre-rift conductive geotherm, geotherm at the end of the termination rifting and a post-rift geotherm 12 million years after the termination of rifting. The post-rift geotherm is calculated assuming conductive cooling of the geotherm applying the McKENZIE (1978) lithospheric extension model

$\rightarrow$ 6. ábra.Pre-rift konduktív hömérséklet-mélység profil (sürün szaggatott vonal), hömérséklet közvetlenül a riftesedés után (folytonos vonal), poszt-rift hömérséklet 12 millió évvel a riftesedés vége után (ritkán szaggatott vonal). A poszt-rift hömérsékletet a MCKENZIE (1978) féle litoszféra-megnyúlási modell alapján számitottuk. Ebben a modellben a litoszféra a megnyúlást követôf felfütődés után konduktiv módon hül than the crust (Figure 6, RoYDEN et al. 1983). Later studies confirmed this conclusion either by analyzing the heat flow (LENKEY 1999) or by numerical modelling of the lithospheric extension (BALÁZS et al. 2021). Following extension the

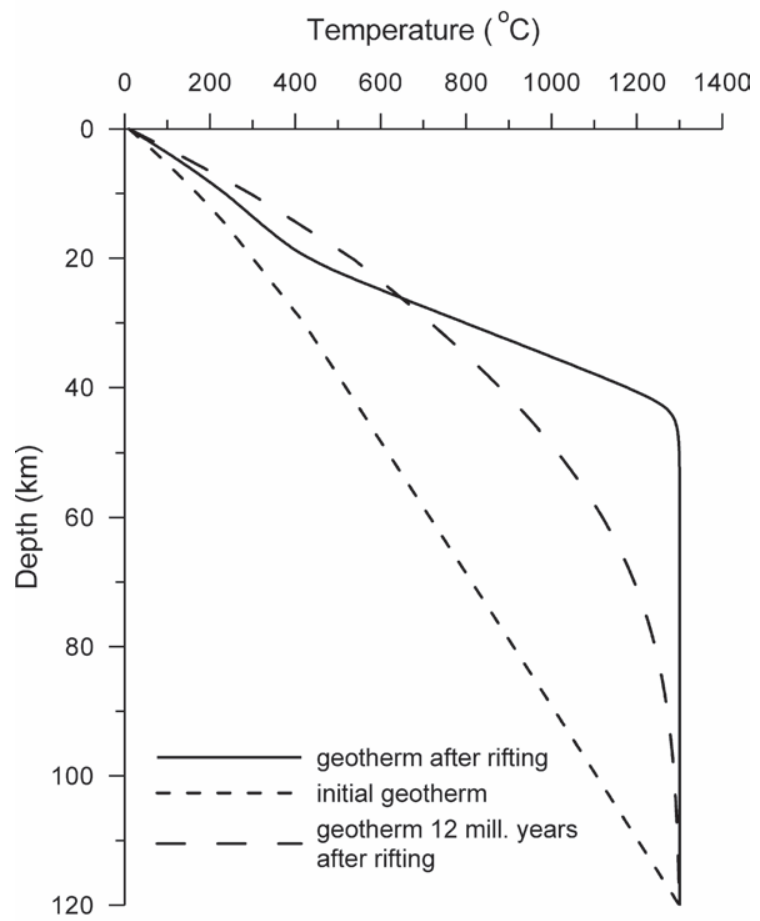


lithosphere begins to cool, which lasts for 100 million years, and finally, the temperature in the lithosphere approaches its pre-rift state (McKenZIE 1978). In the Pannonian Basin 12 million years have passed since the termination of rifting, consequently it is still hot, and it is in the cooling phase (Figure 6).

The heat flow is not uniformly high in Hungary, but it depends on the amount of thinning of the lithosphere and other geological and geophysical processes. The strongest effect on the temperature distribution in the crust is implied by groundwater flow. The low heat flow values are due to meteoric origin groundwater flow in fractured and karstified carbonate rocks in the Transdanubian Range, Bükk Mts. and Aggtelek-Gömör Karst area. The areas cooled by the downward groundwater flow are larger than the areas heated by the upward flow. The downward groundwater flow cools the recharge area at least until $2 \mathrm{~km}$ depth (see also Figures 7, 8 , 9 ), but quasy horizontal flow of the cold water cools also the covered part of the karstic aquifer even at $3 \mathrm{~km}$ depth (Figures $1 c$ and 10). The upward groundwater flow mainly heats the upper $500 \mathrm{~m}-1 \mathrm{~km}$ of the subsurface. Since the heat flow map was constructed from temperatures observed below $1 \mathrm{~km}$, the high heat flow of the upward groundwater flow is visible only at south of Budapest and suspected at south of the Bükk Mts. On the other hand, the discharge areas characterized by elevated temperature are clearly present on the temperature shown at $500 \mathrm{~m}$ depth (Figure 7).
Groundwater flow also occurs in the sediments, but its vertical flux is considerably less than in the carbonates, because of the lower vertical permeability, and thus the associated heat flow anomalies are in the error range of the heat flow estimates except a few places (e.g. Tiszakécske).

Areas with the highest heat flow in the southern part of Hungary are located in the Mecsek Mts. and over the Battonya basement high (covered with 800-1000 m thick sediments), because heat flow is refracted towards the basement highs comprising of good conductivity crystalline and metamorphic rocks. On the contrary, the basin areas filled with thick sedimentary sequences are characterized by lower heat flow density of $80 \mathrm{~mW} / \mathrm{m}^{2}$ e.g. in the Little Hungarian Plain, Makó Trough and Békés depression. It is partly due to heat refraction, and partly because the sediments have not reached thermal equilibrium yet due to high sedimentation rate during the Neogene and Quaternary (LENKEY 1999).

From the viewpoint of geothermal energy utilization temperature is one of the key parameters. We constructed temperature maps at $500 \mathrm{~m}, 1 \mathrm{~km}, 2 \mathrm{~km}$ and $3 \mathrm{~km}$ depths (Figures 7, 8, 9 and 10, respectively). 90\% of the produced thermal water in Hungary comes from shallower depth than $2 \mathrm{~km}$ (SZANYI \& KovÁcS 2010), but there are proven, not exploited reservoirs in the basement, too (STEGENA et al. 1994). That is why the temperature at $3 \mathrm{~km}$ depth is presented. Assuming constant heat flow density in a borehole we calculated the temperature as the function of depth using

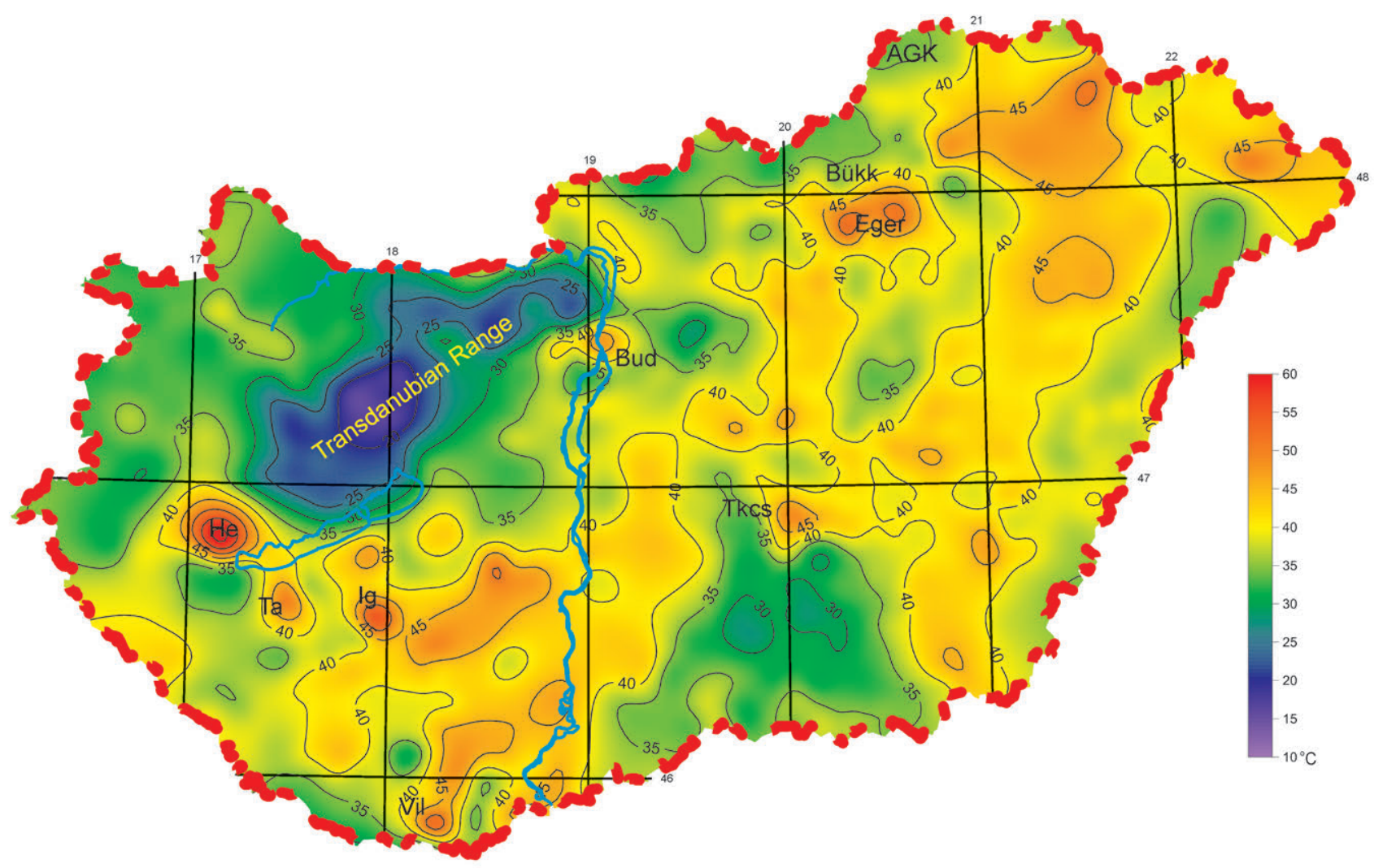

Figure 7. Temperature at $500 \mathrm{~m}$ depth below surface. The contour interval is $5{ }^{\circ} \mathrm{C}$

He: Hévíz, Ta: Táska, Ig: Igal, Vil: Villány Mts., Bud: Budapest, Tkcs: Tiszakécske, AGK: Aggtelek-Gömör Karst

7. ábra. Hömérséklet $500 \mathrm{~m}$ mélységben. Az izovonalak osztásköze $5{ }^{\circ} \mathrm{C}$

He: Héviz, Ta: Táska, Ig: Igal, Vil: Villányi-hegység, Bud: Budapest, Tkcs: Tiszakécske, AGK:Aggtelek-Gömöri-karszt 


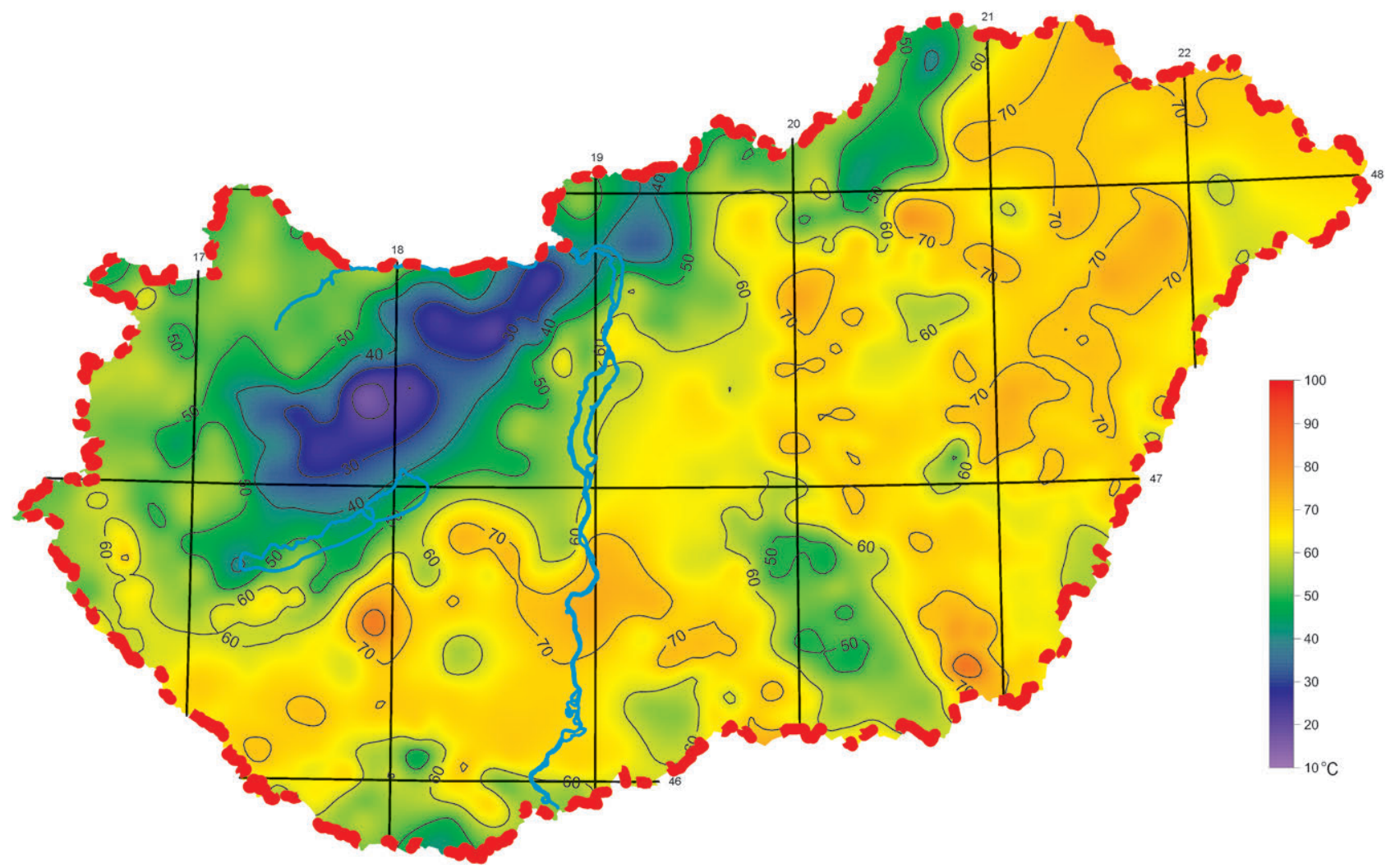

Figure 8. Temperature at $1 \mathrm{~km}$ depth below surface. The contour interval is $10{ }^{\circ} \mathrm{C}$

8. ábra. Hömérséklet $1 \mathrm{~km}$ mélységben. Az izovonalak osztásköze $10{ }^{\circ} \mathrm{C}$

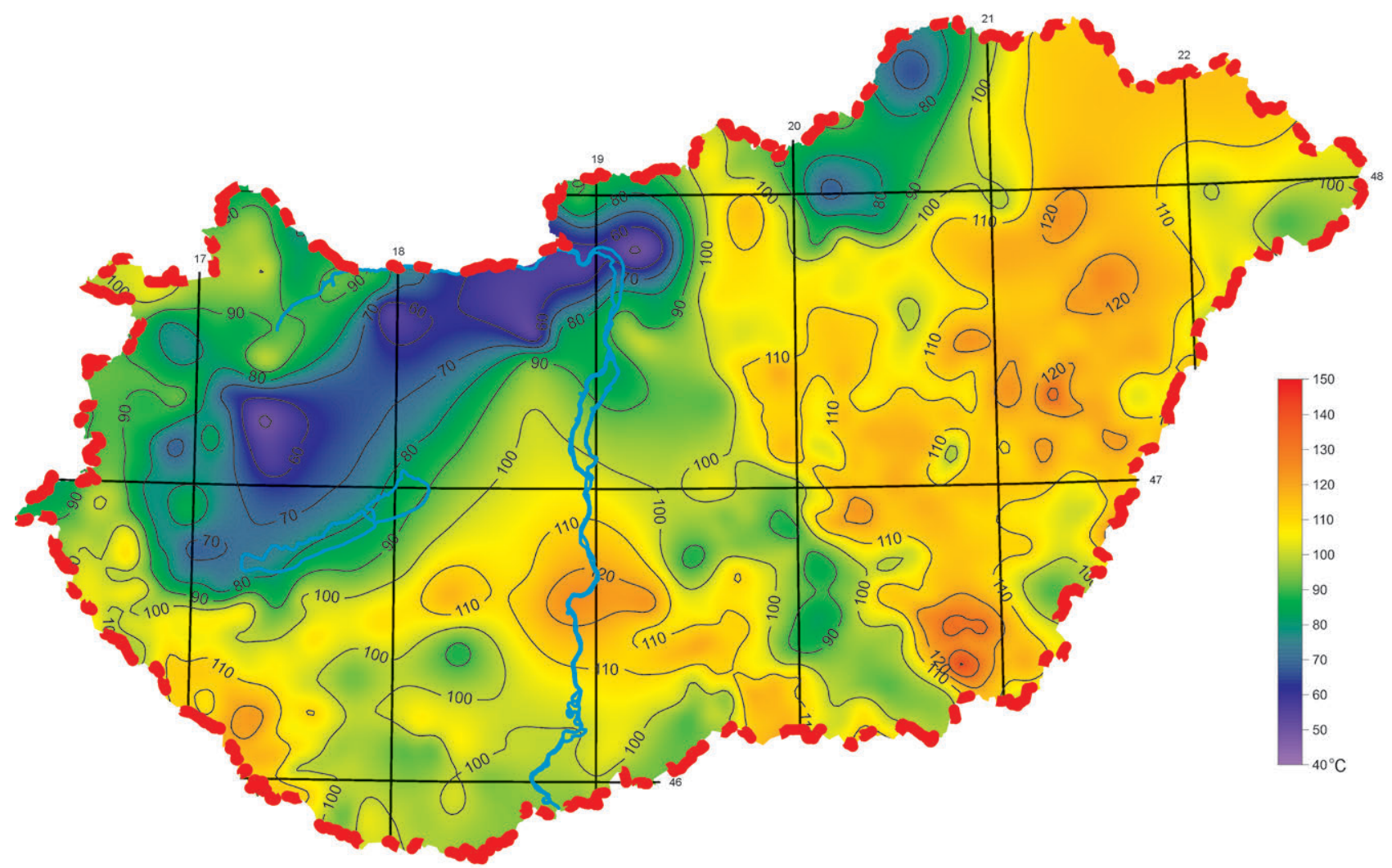

Figure 9. Temperature at $2 \mathrm{~km}$ depth below surface. The contour interval is $10{ }^{\circ} \mathrm{C}$

9. ábra. Hömérséklet $2 \mathrm{~km}$ mélységben. Az izovonalak osztásköze $10{ }^{\circ} \mathrm{C}$ 


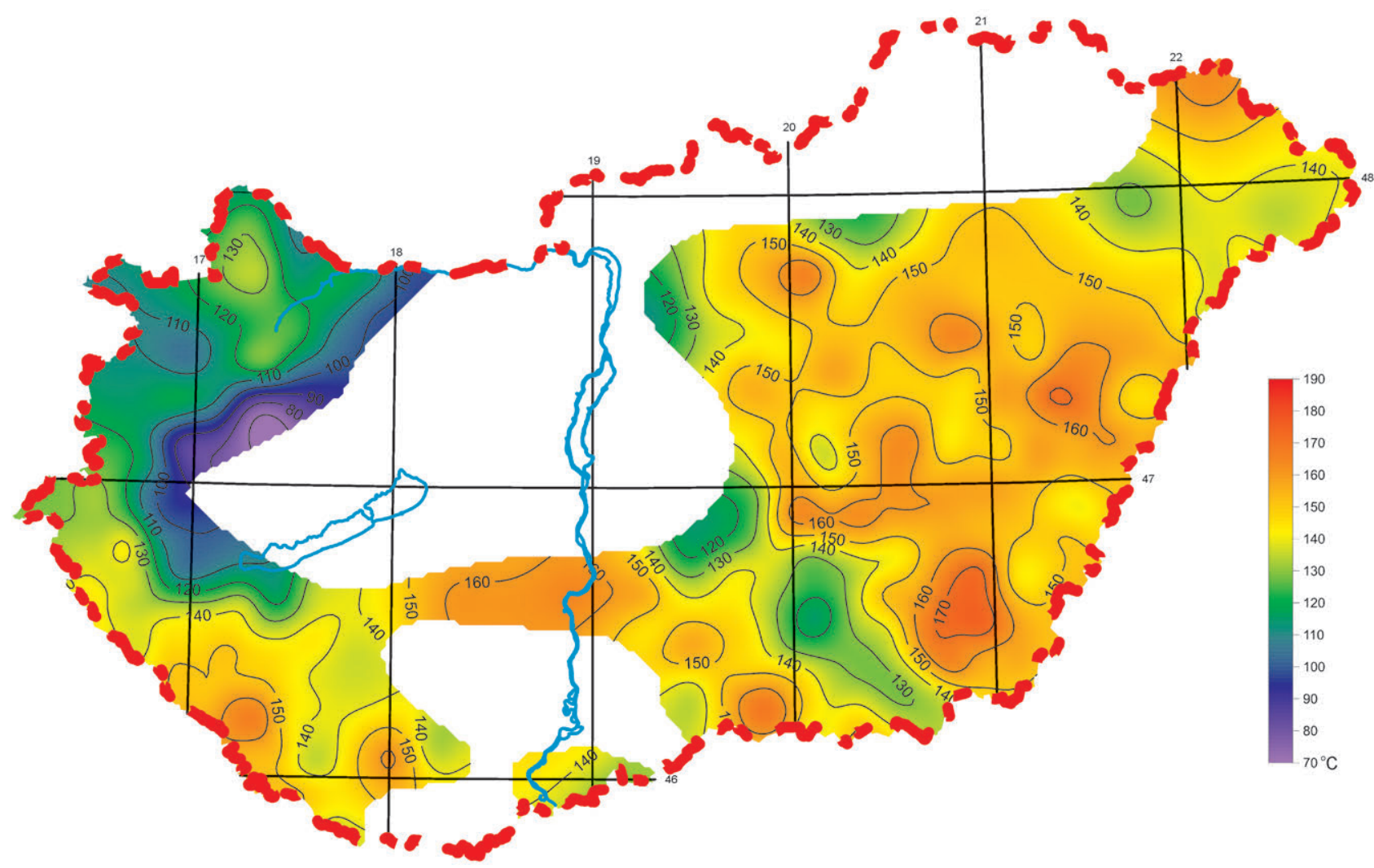

Figure 10. Temperature at $3 \mathrm{~km}$ depth below surface. The contour interval is $10^{\circ} \mathrm{C}$. In the blanked areas boreholes deeper than $1.7 \mathrm{~km}$ do not exist 10. ábra. Hömérséklet $3 \mathrm{~km}$ mélységben. Az izovonalak osztásköze $10^{\circ} \mathrm{C}$. A fehéren hagyott területeken nincsen 1,7 km-nél mélyebb fúrás vagy kút, melyben hömérsékletet mértek volna. Nem akartuk az ennél sekélyebb mélységben mért hömérsékletet 3 km mélységbe extrapolálni, ezért hagytukfehéren ezeket a területeket

formula A3 (Appendix). For examples of the calculated temperature curves see Figure 1. As we discussed earlier the heat flow may vary with depth due to groundwater flow. In order not to use shallow and disturbed heat flow values, thus not to extrapolate downward the nearsurface temperature anomalies we made a selection in the boreholes and wells based on their bottom depth. Calculating the temperature at a given horizon $\left(z_{h}\right)$ we applied formula A3 only in those boreholes and wells which bottom depth fell between $50 \%$ and $200 \%$ of $z_{h}$. Basically, we calculated the mean heat flow characterizing the above depth range, and it was used in the temperature extrapolation. We note that if the bottom of the borehole fell into the given depth range, then we used every temperature observations in the borehole in calculating the mean heat flow (A1, Appendix), even those ones which were in shallower depth than the depth range. The number of boreholes and wells used in the temperature extrapolation is given in Table I. There are no temperature observations deeper than $1700 \mathrm{~m}$ in the northern and southern part of the country, thus these areas are left blank in Figure 10.

The mean temperature at $500 \mathrm{~m}$ depth is about $40{ }^{\circ} \mathrm{C}$ (Figure 7). Temperatures significantly different from this value indicate groundwater flow: the Transdanubian Range is characterized by low temperature less than $25^{\circ} \mathrm{C}$ due to downward groundwater flow, and there are several small areas (Hévíz, Táska, Igal, Villány, Budapest, Eger, Tiszakécske), where the temperature is higher than $50^{\circ} \mathrm{C}$. In these areas upward groundwater flow takes place. In some places the water discharges to the surface in warm springs (e.g. Hévíz, Budapest, Eger), in other places the warm water heats up the overlying sediments (e.g. Táska, Igal). Most of these warm thermal anomalies dissipate with depth, which is a clear evidence that they are caused by upward groundwater flow, and at $2 \mathrm{~km}$ depth most of them disappear except the Táska and Igal anomalies. They belong to elongated lines of thermal anomalies running in ENE-WSW direction (Figures 8 and 9) and are associated with the elevated carbonate basement, in which probably thermal convection occur. At $1 \mathrm{~km}$ and $2 \mathrm{~km}$ depths the pattern of the temperature distribution is similar: the lowest temperatures are observed around the carbonate outcrops and they are attributed to downward and horizontal flow of groundwater. E.g. the meteoric water, which recharged in the Bakony Mountains, flows towards northwest in the carbonate reservoir (see also

Table I. Number of boreholes and wells $(\mathrm{N})$ in a given depth range used in calculating the temperature at the appropriate horizon

I. táblázat. Az adott mélységbe történt interpolálásnál figyelembe vett mélységintervallum és azon fúrások és kutak száma, amelyekben ebben az intervallumban végeztek hömérsékletmérést

\begin{tabular}{|c|c|c|}
\hline Horizon $(\mathrm{km})$ & Depth range $(\mathrm{km})$ & $\mathrm{N}$ \\
\hline 0.5 & $0.3-1$ & 1926 \\
\hline 1 & $0.5-2$ & 1488 \\
\hline 2 & $1-4$ & 1877 \\
\hline 3 & below 1.7 & 1387 \\
\hline
\end{tabular}


Figure 1c) and after reaching the Rába fault one branch turns to northeast and the other to southwest (Figures 8 and 9). The southwest branch is forced to make another turn to southeast probably by a NW-SE directed fault and finally, it feeds the Hévíz Lake.

The highest temperatures are observed above structural basement highs and they can be attributed to thermal convection in the carbonate basement and/or to heat refraction where the basement is crystalline or metamorphic. At $2 \mathrm{~km}$ depth there are several areas in the central and eastern part of the country, where the temperature is above $120^{\circ} \mathrm{C}$. Unfortunately, in these areas permeable rocks are not present at this depth, because the $120{ }^{\circ} \mathrm{C}$ isotherm is located in the crystalline, metamorphic basement, or in impermeable marls. Permeable sediments are found until $2 \mathrm{~km}$ depth in the Little Hungarian Plain and the Makó Trough, where the temperature is between $90{ }^{\circ} \mathrm{C}$ and $100{ }^{\circ} \mathrm{C}$, or slightly above $100^{\circ} \mathrm{C}$. This is the highest temperature thermal water, which can be produced from the Neogene sandstones. Higher temperature water can be found only in larger depth in the fractured and karstic carbonates located in the basement of the sediments (STEGENA et al. 1994). The temperature at 3 $\mathrm{km}$ depth (Figure 10) is known in the basin areas: Great Hungarian Plain, Little Hungarian Plain and the Zala Basin - Dráva Trough. In other places deep boreholes were not drilled. In these places we should extrapolate the temperature from shallow depth. As the condition of constant heat flow may not be fulfilled leading to erroneous temperatures, and additionally, the error becomes larger with increasing depth, it is the best to leave these areas blank. Even in those places where deep temperature data exist, the temperature varies highly, which is probably an artefact of the extrapolation. We can state that the temperature is lower in the Little Hungarian Plain and the Makó Trough $\left(110-130{ }^{\circ} \mathrm{C}\right)$ and highest in the Algyô and Battonya highs $\left(150-180^{\circ} \mathrm{C}\right)$, and in other places it varies between $130{ }^{\circ} \mathrm{C}$ and $160{ }^{\circ} \mathrm{C}$. The Algyő and Battonya highs are favorable places to create artificial reservoirs by hydraulic fracturing, (Enhanced Geothermal System, EGS), because the temperature is high enough in relatively shallow depth of 3-4 km, thus the drilling costs can be lowered.

\section{Discussion}

The heat flow map presented in Figure 5 is similar to the former one (DövÉNYI et al. 2002) except that in the new version the heat flow is $10 \mathrm{~mW} / \mathrm{m}^{2}$ lower in the NE part of the Great Hungarian Plain and $10 \mathrm{~mW} / \mathrm{m}^{2}$ higher in the southern part of the country: in the Mecsek Mountains (120 $\mathrm{mW} / \mathrm{m}^{2}$ ), in the Makó Trough and above the Battonya high $\left(110 \mathrm{~mW} / \mathrm{m}^{2}\right)$. The former map was based on 120 data, the new one is based on 2001 data, which may explain the difference between the values.

In this paper we presented the temperature data in the simplest form as temperature maps at given depths, and we interpreted them in terms of groundwater flow and heat transport. Till $2 \mathrm{~km}$ depth there are enough data and the extrapolation of temperature does not influence the results much. In larger depth there are less data, and due to the extrapolation of shallow temperatures to larger depth the reliability of deep temperatures decreases.

One way to avoid this problem is numerical modelling of the temperature by solving the heat transport equation in 3D, and fitting the calculated temperatures to the observed ones by changing the thermal and/or hydraulic parameters of the model. The best is to solve the non-steady state equation, which includes both conductive and convective heat transport and heat production. However, before solving the heat transport equation we must solve the equations, which govern the groundwater flow, and the obtained groundwater fluxes will determine the convective term in the heat transport equation. This coupled groundwater flow and heat transport modelling requires the knowledge of the hydraulic conductivity, the thermal conductivity and the heat production of rocks in 3D. Regional scale groundwater flow model exist for the porous sediments in the Great Hungarian Plain (VISZKOK 2001) and for the karstic water flow in the carbonates in the Transdanubian Range (CSEPREGI \& LORBERER 1989), but in these models heat transport was not taken into account. On the other hand, lithospheric scale 3D conductive heat transport models exist for Hungary (BÉKÉSI et al. 2017) and for the western part of the Pannonian basin (LENKEY et al. 2017). In the first model the thermal conductivity and heat production of rocks was varied according to EMERICK \& REYNOLDS (2013) in order to fit the calculated temperatures to the observed ones. In the second model the non-steady temperature field of the lithosphere was modeled assuming Middle Miocene lithospheric extension. Naturally, these conductive models are not able to predict the temperature in those areas, where groundwater flow happens. As groundwater flow happens mainly in the upper few kilometers of the crust, it is not worth modeling the whole lithosphere in groundwater flow models. The importance of lithospheric scale conductive models is that the calculated temperature or heat flow can be applied as a lower boundary condition in the regional or local scale groundwater and coupled heat transport models. Such local models can be used for geothermal research and exploration to predict the temperature at great depth more reliably than simple extrapolation. A regional scale groundwater and coupled heat transport model for some parts of the country or the whole Pannonian Basin, which explains the observed hydraulic heads and temperatures is a future task.

\section{Conclusions}

The temperature distribution in the upper $2-3 \mathrm{kms}$ of the crust in Hungary is well known based on the abundant temperature data. The groundwater flow, especially karstic water flow, has a very strong signal in the temperature field and the heat flow, and based on the thermal anomalies the flow system can be tracked. 
There are a few hundred thermal conductivity data based on laboratory measurements on core samples. Presently efforts are made to determine the thermal conductivity from well-logs. It will considerably increase the number of thermal conductivity data, which will increase the reliability of heat flow determinations and thermal models.

Using the thermal conductivities regional and local 3D groundwater flow and coupled heat transport models can be constructed and temperature data from database can be used to verify these models. Such way 3D thermal modeling allows the prediction of temperature in great depth, which may reduce the risk of exploration of high temperature reservoirs.

\section{Acknowledgement}

This paper is dedicated to the memory of Péter DöVÉNYI and Ferenc HorváTH, who initiated the systematic thermal conductivity measurements in Hungary, collected the available temperature data and constructed the Geothermal Database of Hungary, which is still in use. We thank Ladislaus RYBACH’s, János SZANYI’s (Guest Editor) and an anonymous reviewer's comments and questions, which considerably contributed to the improvement of the manuscript. This work was supported by the National Research, Development and Innovation Office in the framework of project No. K 129279.

\section{References - Irodalom}

ALFÖLDI L. 1979: Budapesti hévizek. VITUKI, Budapest, 102 p.

Balázs, A., Matenco, L., Granjeon, D. K., Francois, T. \& Sztanó, O. 2021: Towards stratigraphic-thermo-mechanical numerical modelling: Integrated analysis of asymmetric extensional basins. - Global and Planetary Change https://doi.org/10.1016/ j.gloplacha.2020.103386

BÁLINT, A. \& SZANYI, J. 2015: A half century of reservoir property changes in the Szentes geothermal field. - Central European Geology 58/1-2, 28-49. https://doi.org/10.1556/24.58.2015.1-2.2

Békési, E., Lenkey, L., Limberger, J., Porkoláb, K., Balázs, A., Bonté, D., Vrijlandt, M., Horváth, F., Cloetingh, S., van Wees, J-D. 2017: Subsurface temperature model of the Hungarian part of the Pannonian Basin. - Global and Planetary Change 171, 48-64. https://doi.org/10.1016/j.gloplacha.2017.09.020

Bélteky, L., Alföldi, L., Korim, K., Marcell, F., Papp, Sz., Rémi, R., Simon, F. \& UrbancseK, J. (szerk.) 1965: Magyarország hévízkútjai I. (Thermal wells of Hungary.). -VITUKI, Budapest, 420 p.

BoldizsÁr, T. 1956: Measurement of terrestrial heat flow in the coal mining district of Komló. Acta Technica Academiae Scientiarum Hungaricae 15, 219-227.

BoldizsÁr, T. 1967: Terrestrial heat and geothermal resources in Hungary. - Bulletin Volcanologique 30, 221-227. https://doi.org/ $10.1007 / \mathrm{bf} 02597670$

Bredehoeft, J. D. \& PAPAdopulos, I. S. 1965: Rates of vertical groundwater movement estimated from the Earth's thermal profile. Water Resource Research 1/2, 325-328. https://doi.org/10.1029/wr001i002p00325

Bullard, E. C. 1939: Heat flow in South Africa. - Proceedings Royal Society of London, Ser. A. 173, 474-502. https://doi.org/10.1098/ rspa.1939.0159

Cloetingh, S., van Wees, J. D., Ziegler, P. A., Lenkey, L., Beekman, F., Tesauro, M., Förster, A., Norden, B., Kaban, M., Hardebol, N., Bonté, D., Genter, A., Guillou-Frottier, L., Ter Voorde, M., Sokoutis, D., Willingshofer, E., Cornu, T. \& WóRUM, G. 2010: Lithosphere tectonics and thermo-mechanical properties: an integrated modelling approach for Enhanced Geothermal Systems exploration in Europe. - Earth-Science Reviews 102, 159-206. https://doi.org/10.1016/j.earscirev.2010.05.003

CSEPREGi, A. \& Lorberer, Á. 1989: Computer simulation of karstwater-level changes in the Transdanubian Mountain Ranges. - Xth International Speleological Congress, 1989, MTESZ-MKBT, Budapest, vol. II, 446-469.

DowdLe, W. L. \& CoBB, W. M. 1975: Static formation temperature from well logs - an empirical method. - Journal of Petroleum Technology 27, 1326-1330. https://doi.org/10.2118/5036-pa

DöVÉNYI P. 1994: A Pannon-medence litoszférájának geofizikai vizsgálata. - Kandidátusi értekezés, Eötvös Loránd Tudományegyetem, (Geophysical investigations of the lithosphere of the Pannonian basin PhD Thesis), Budapest, $127 \mathrm{p}$.

DövÉnYI, P. \& HoRváth, F. 1988: A review of temperature, thermal conductivity, and heat flow data from the Pannonian Basin. - In: Royden, L. H. \& Horváth, F. (eds): The Pannonian Basin, a Study in Basin Evolution. - American Association of Petroleum Geologists Memoir 45, 195-233.

DövénYi, P., HorVÁth, F., LIEBe, P., GÁlfi, J. \& ERKI, I. 1983: Geothermal conditions of Hungary. - Geophysical Transactions 29/1, 3-114.

DövénYi, P., Horváth, F. \& Drahos, D. 2002: Hungary. - In: Hurter, S. \& HaEnEl, R. (eds.): Atlas of Geothermal Resources in Europe. - Publication No. 17811 of the European Comission, Office for Offical Publications of the European Communities. L-2985, Luxembourg, 36-38.

EMERICK, A. A., \& REYNolds, A. C. 2013: Ensemble smoother with multiple data assimilation. - Computer Geosciences 55, 3-15. https:// doi.org/10.1016/j.cageo.2012.03.011

ERKI, I. 1984: Vizsgálatok a kőzetek hővezetőképességének köréből. - Doktori dolgozat, ELTE, Budapest, 192 p. (Study of the thermal conductivity of rocks. $-\mathrm{PhD}$ Thesis.)

GÁLFI J. \& LIEBE P. 1977: Magyarország geotermikus hőmérséklettérképei a vízfeltáró fúrások alapján. - Kutatási Jelentés, VITUKI adattár, Budapest. 
HoRner, D. R. 1951: Pressure bulid-up in wells. - Proceedings Third World Petroleum Congress, The Hague.

Horváth, F., PAP, N., RemÉnYi, P., Tóth, T. (eds) 2014: Geothermal Resource Assessment of the Drava Basin. -ID Research Kft., 1-221.

Horváth, F., Musitz, B., Balázs, A., VÉGh, A., Uhrin, A., NÁdor, A., Koroknai, B., Pap, N., Tóth, T. \& Wórum, G. 2015: Evolution of the Pannonian basin and its geothermal resources. - Geothermics 53, 328-353. https://doi.org/10.1016/j.geothermics.2014.07.009

JARVIS, G. T. \& MCKENZIE, D. P. 1980: Sedimentary basin formation with finite extension rates. - Earth and Planetary Science Letter 48, 42-52. https://doi.org/10.1016/0012-821x(80)90168-5

Jaupart, C., LABrosse, S. \& Mareschal, J.-C. 2007: Temperatures, heat and energy in the mantle of the Earth. - In: BERCOVICI, D. (ed.): Treatise on Geophysics, Mantle Convection 7, Elsevier, 253-303. https://doi.org/10.1016/b978-044452748-6/00114-0

KAPPELMEYER, O. \& HAENEL, R. 1974: Geothermics with special reference to application. - Geoexploration Monographs 1/4, Gebrüder Borntraeger, Berlin, Stuttgart, 238 p.

KeLVIN, W. T. 1863: On the secular cooling of the earth. - Transactions of the Royal Society of Edinburgh 23, 157-170.

KoRIM K. 1972: Nagymélységú porózus víztároló képződmények jellemzői és múködésmódja (Features of deep porous aquifers). Vízügyi Közlemények 54/4, 369-392 (in Hungarian).

LENKEY, L. 1999: Geothermics of the Pannonian basin and its bearing on the tectonics of basin evolution. - PhD thesis, Vrije Universiteit, Amsterdam, $215 \mathrm{p}$.

Lenkey, L., RaÁb, D., Goetzl, G., Lapanje, A., NÁdor, A., Rajver, D., Rotár-Szalkai, Á., Svasta, J. \& Zekiri, F. 2017: Lithospheric scale 3D thermal model of the Alpine-Pannonian transition zone. - Acta Geodaetica Geophysica 50/1, 1-22. https://doi.org/ 10.1007/s40328-017-0194-8

Magyar, I., Radivojevic, D., Sztanó, O., Synak, R., Ujszászi, K. \& PócsiK, M. 2013: Progradation of the paleo-Danube shelf margin across the Pannonian Basin during the Late Miocene and Early Pliocene. - Global Planetary Change 103, 168-173. https:// doi.org/10.1016/j.gloplacha.2012.06.007

MÁDL-SzŐNYI, J. \& TóTH, Á. 2015: Basin-scale conceptual groundwater flow model for an unconfined and confined thick carbonate region. - Hydrogeology Journal 23, 1359-1380. https://doi.org/10.1007/s10040-015-1274-x

MCKenZIE, D. 1978: Some remarks on the development of sedimentary basins. - Earth and Planetary Science Letter 40, 25-32. https:// doi.org/10.1016/0012-821x(78)90071-7

NÁdor, A., KujBus, A. \& Tóth, A. N. 2019a: Geothermal energy use, country update for Hungary. - European Geothermal Congress, 11-14 June 2019, The Hague, The Netherlands. Abstracts.

NÁdor, A., Sebess-Zilahi, L., Rotár-Szalkai, Á., Gulyás, Á. \& Markovic, T. 2019b: New methods of geothermal potential assessment in the Pannonian basin. - Netherlands Journal of Geosciences 98, e10. https://doi.org/10.1017/njg.2019.7

Paks-2 NPP. 2016: Site investigation of the Paks-2 Nuclear Power Plant, Report.

Pollack, H. N., HuRTER, S. J. \& JohnSON, J. R. 1993: Heat loss from the Earth's interior: analysis of the global data set. - Reviews of Geophysics 31, 267-280. https://doi.org/10.1029/93rg01249

RANALLI, G. 1995: Rheology of the Earth. - Chapman and Hall, London, 413 p.

REZESSY G., SZANYI J. \& HÁMOR T. 2005: A geotermikus energiavagyon állami nyilvántartásának előkészítéséről. I. fázis. - Jelentés, Magyar Geológiai Szolgálat, Budapest, 85 p. (Report on the registration of geothermal resources in Hungary. First phase. Report, Hungarian Geological Survey, Budapest, 85 p.)

Rotár-Szalkai, Á., NÁdor, A., Szốcs, T., Maros, Gy., GoetZl, G. \& Zekiri, F. 2017: Outline and joint characterization of transboundary geothermal reservoirs at the western part of the Pannonian basin. - Geothermics 70, 1-16. https://doi.org/10.1016/ j.geothermics.2017.05.005

Royden, L. H., Horváth, F., Nagymarosy, A. \& Stegena, L. 1983: Evolution of the Pannonian basin system: 2. Subsidence and thermal history. - Tectonics 2, 91-137. https://doi.org/10.1029/tc002i001p00091

StAPFF, F. M. 1883: Some results of observations on underground temperature during the construction of the St. Gotthardtunnel. Proceedings of North England Institute of Mining and Mechanical Engineers 32, 14-34.

Stegena, L., Horváth, F., LANDY, K., NAGY, Z. \& RuMPLER, J. 1994: High-temperature geothermal reservoir possibilities in Hungary. Terra Nova 6, 282-288. https://doi.org/10.1016/0148-9062(95)90155-8

SZANYI, J. \& KoVÁCS, B. 2010: Utilization of geothermal systems in South-East Hungary. - Geothermics 39, 357-364. https://doi.org/ 10.1016/j.geothermics.2010.09.004

SZANYI J., NÁDOR A. \& MADARÁsz T. 2021: A geotermia helyzete Magyarországon az elmúlt 150 év tükrében. - Földtani Közlöny 151/1, 79-102.

Tótн A. E. 2016: Magyarország geotermikus felmérése 2016. - Magyar Energetikai és Közmú-szabályozási Hivatal, Budapest. (Geothermal Cadaster of Hungary), $182 \mathrm{p}$.

VISZKOK, J. 2001: Subsurface fluid flow simulation with finite element method in the east Pannonian Basin. - PhD Thesis, University of Geneva, 134 p.

ZILAHI-SEBESS L. \& GyURICZA Gy. (szerk.) 2011-13: 17 geotermikus koncessziós terület komplex érzékenységi és terhelhetôségi vizsgálati tanulmánya. - Magyar Állami Földtani, Geofizikai és Bányászati Adattár, Budapest https://mbfsz.gov.hu/vizsgalatijelentes

Zilahi-Sebess L., ANDRÁssy L. \& Maros Gy. 2008: Petrofizikai módszerfejlesztés. - ELGI, FGBA Adattár.

ZsigmondY V. 1879: A városligeti artézi kút Budapesten. - Földtani Közlöny 9, 128-131.

Kézirat beérkezett: 2020. 06. 23. 


\section{Appendix \\ Calculation of the heat flow and the temperature-depth function in a borehole}

We calculated the heat flow $\left(q_{i}\right)$ at every depth where temperature $\left(T_{i}\right)$ was observed:

$$
q_{i}=\frac{T_{i}-T_{0}}{\sum_{j=1}^{M} \frac{h_{i}}{\lambda_{j}}}
$$

where $\sum_{j=1}^{M} \frac{h_{i}}{\lambda_{j}}$ is the thermal resistivity until the depth of the temperature observation $\left(z_{i}\right)$ and $T_{0}$ is the surface temperature. $\lambda_{\varphi}$ is calculated according to the lithology of the borehole and the thermal conductivity-depth trends (Figure 3 ). $h_{i}$ is the thickness of a layer with thermal conductivity $\lambda$. The mean heat flow is calculated by weighting the heat flow values $\left(q_{i}\right)$ with weights, which decrease as the reliability (quality) of the temperature data, and $\mathrm{N}$ is number temperature, and thus heat flow observations:

$$
q=\frac{1}{\sum_{i=1}^{N}\left(9-S_{i}\right)^{2}} \sum_{i=1}^{N} q_{i}\left(9-S_{i}\right)^{2}
$$

where $S_{i}$ is the class of the temperature data. Note that $S=1$ and $S=8$ means the best and the worst quality, respectively. The temperature-depth function is calculated assuming constant heat flow as follows:

$$
T(z)=T_{0}+q \sum_{i=1}^{M^{\prime}} \frac{h_{i}}{\lambda_{i}}
$$

where $\sum_{j=1}^{M^{\prime}} h_{i}=z$ 